\title{
VARIABILITY OF THE LIPID PEROXIDATION POTENTIAL IN THE ERYTHROCYTES OF THE DOMESTIC FOWL
}

\author{
M. SMUTNÁ, E. PETROVSKÝ, J. PODANÝ, A. KONEČNÝ, O. SYNEK
}

Department of Chemistry, Physics and Biochemistry, University of Veterinary Science 61242 Brno; Institute of Farm Animal Physiology and Genetics, Czechoslovak Academy of Sciences, Liběchov; Department of Anatomy, Farm Animal Physiology and Biochemistry, University of Agriculture, Brno

Received March 11, 1978

\begin{abstract}
Smutná M., E. Petrovský, J. Podaný, A. Konečný, O.Synek : Variability of the Lipid Peroxidation Potential in the Erythrocytes of the Domestic Fowl. Acta vet. Brno, 47, 1978: 137-143.

The present study deals with investigations of the lipid peroxidation of erythrocyte membranes of the domestic fowl. When elaborating the optimal method, hydrogen peroxide was used as activator. Studies of the variability of the concentration of the lipid peroxidation potential showed that its variability was affected by several factors, such as age, sex, sexual maturity and nutrition. Before sexual maturity no significant differences were found between the fowls of both sexes. In the period of sexual maturity the hens had a higher concentration of malonyldialdehyde than cocks. In samples taken from birds bred and kept using standard mixtures according to the Czechoslovak formula (KZK) the level of malonyldialdehyde was affected neither by age nor by sex. On the other hand, feeding a biologically better mixture (K) and a mixture with a high content of maize during the egg laying period led to the manifestation of statistically significant differences due to age and sex.
\end{abstract}

Age, sex, chicken, nutrition.

The basic building stones of biological membranes, the phospholipids, represent more than one half of the total lipids of membranes of erythrocytes. The main phospholipids of erythrocyte membranes are phosphatidylcholine, phosphatidyletanolamine and sphingomeylin; to a smaller extent also phosphatidylinositol, phosphatidylserin, lysophosphatidylcholine, and phosphatidic acid.

The lipid component of the membrane, especially the polyunsaturated fatty acids esterified in phospholipids, were found to respond very sensitively to the effect of chemical, physical and biological catalysts in that they changed their structure and properties. In this connection, great attention was devoted to the peroxidation of polyunsaturated fatty acids in various biological systems (Thiele and Huff 1960; Heath and Packer 1965; Barber 1966; Wills 1969; Sharma et al. 1972; Stossel et al. 1974). The breakdown of polyunsaturated fatty acids leads to the formation of a mixture of various degradation products. Primarily, free radicals are formed temporarily, secondarily aldehydes, namely malonyldialdehyde, hydroxy acids, polymers, etc. (Bernheim 1963; Barber and Bernheim 1967; Placer 1968). The determination of malonyldialdehyde (MDA) by means of colour reaction with 2-thiobarbituric acid is considered to be a reliable and relatively widely spread method of lipid peroxidation studies, along with a time and labour consuming method of determination of conjugated dienes, oxidation of reduced nicotinamideadenindinucleotidphosphate coenzyme, or by measuring the oxygen consumption.

Studies of lipid peroxidation of blood elements are concentrated to present problems of medicine, associated namely with blood transfusions, such as e. g. the ageing of blood platelets accompanied with the loss of their normal function, decreased viability of all cellular elements after a long-term. storage of blood, etc. (Okuma et al. 1970). Many details are known about the dynamics of lipid 
peroxidation in these systems. On the contrary, lipid peroxidation of poultry erythrocytes has not yet been elaborated. Therefore, the aim of the present study has been to investigate the peroxidation of erythrocytes of the domestic fowl and to acquire data on the variability of the lipid peroxidation potential of this animal species.

\section{Materials and Methods}

For the experiments we used hens and cocks of the Rhode Island Red breed (RIR, 196 days old) and Barred Plymouth Rock (BPR, 123 and 205 days old, resp.) from the School Farm of the University of Agriculture Brno. Fowls of the BPR breed were taken from two groups with different nutrition. The standard group was fed a $\mathrm{K}$ and $\mathrm{KZK}$ mixture, the other group was fed a $\mathrm{K}$ mixture over the whole period of rearing. During the egg laying period the first group was fed a NP mixture, the other group an experimental mixture with a high maize content $(50 \%)$.

Erythrocyte suspension: A $5 \%$ suspension of erythrocytes was used for the experiments obtained from citrate blood washed three times in the saline. The number of erythrocytes in the suspension was determined using Bürker's counting chamber.

Deteremination of the MDA concentration: After an aerobic pre-incubation lasting $600 \mathrm{~s}$, the $2.7 \mathrm{ml}$ suspension of erythrocytes was incubated at $310 \mathrm{~K}$ with an activator $(0.3 \mathrm{ml})$ in a Warburg manometric apparatus under continuous shaking: Incubation of the given period of $5.4 \cdot 10^{3} \mathrm{~s}$ was finished by adding $3 \mathrm{ml}$ of $20 \%$ trichloroacetic acid and after $600 \mathrm{~s}$ of standing the precipitate was filtered. The aliquot portion of deproteinized filtrate was mixed with the same volume of $0.5 \% 2$-thiobarbituric acid in $10 \%$ trichloroacetic acid. The mixture was boiled for $600 \mathrm{~s}$ in a water bath, then was cooled and the colouration intensity, dependent on the amount of MDA, was measured on a Specol photocolorimeter (Zeiss Jena) at $535 \mathrm{~nm}$ against a blank. The blank was prepared in an analogical way using a physiological solution $(0.3 \mathrm{ml})$ instead of an activator.

Calibration: The reproducibility of the method was tested by determining the extinction molar MDA coefficient which was prepared by acid hydrolysis of 1,1,3,3-tetraethoxypropane (the firm Fluka). The value of the extinction molar MDA coefficient was $1.44 .10 \mathrm{~m}^{2} \cdot \mathrm{mol}^{-1}$. The results were expressed in $\mu \mathrm{mol}$ of the MDA formed per $10^{4}$ of erythrocytes.

Activators: As an activator we used $0.2 \mathrm{M}$ of hydrogen peroxide; the accuracy of its molarity was determined by titration with potassium permanganate. (In an orientation experiment it was proved that $\mathrm{Cu}^{2+}$ ions used for the activation of lipid peroxidation of various biological materials are inapplicable for erythrocytes of the domestic fowl because they cause turbidity.)

Statistical evaluation of the results consisted in calculations of the basic statistical values $(\bar{x}, \bar{x}, s, V)$ and in finding the significance of differences in the groups studied using variance analysis.

\section{Results}

Determination of the MDA level in RIR hens and cocks at the age of 196 days

Tables 1 and 2 show the basic statistical values of the MDA concentrations of erythrocytes of RIR cocks and hens and comparisons of the difference between sexes using variance analysis. From the tables it is evident that the lipid peroxidation potential of erythrocytes of hens is higher $\left(17.6 \mu \mathrm{mol} .10^{-4}\right.$ of erythrocytes) than that of the cocks $\left(11.2 \mu \mathrm{mol} 10^{-4}\right.$ of erythrocytes). At the same time the variance analysis showed that the difference between sexes is below the limit of significance. Undoubtedly, it is due to the considerable variability of the characteristics given in both sexes and the low number of birds investigated.

Table 1

Basic statistical data on the concentration of malonyldialdehyde in the suspension of red blood corpuscles in the RIR breed after aerobic incubation with $\mathrm{H}_{2} \mathrm{O}_{2}$

\begin{tabular}{|c|c|c|c|c|c|}
\hline \multirow{2}{*}{ Sex } & \multirow{2}{*}{ Number } & \multicolumn{4}{|c|}{ MDA concentration ( $\mu \mathrm{mol} \cdot 10^{-i}$ of erythrocytes) } \\
\hline & & $x$ & ${ }^{8} x$ & $s_{x}$ & $V$ \\
\hline $\begin{array}{l}\text { Cocks } \\
\text { Hens }\end{array}$ & $\begin{array}{l}6 \\
6\end{array}$ & $\begin{array}{l}11.18 \\
17.59\end{array}$ & $\begin{array}{l}1.68 \\
3.07\end{array}$ & $\begin{array}{l}4.12 \\
7.54\end{array}$ & $\begin{array}{l}36.90 \\
42.86\end{array}$ \\
\hline
\end{tabular}


Table 2

Variance analysis of malonyldialdehyde concentration in cocks and hens of the RIR breed

\begin{tabular}{|l|c|c|c|c|}
\hline \multicolumn{1}{|c|}{ Source of variability } & Sum of squares & Degrees of freedom & Variances & Value $F$ \\
\hline \begin{tabular}{l|l|l|l|} 
Between groups \\
Within groups
\end{tabular} & $\begin{array}{r}123.25 \\
369.62\end{array}$ & $\begin{array}{c}1 \\
\text { (1) }\end{array}$ & 36.96 & 3.334 \\
\hline Total & 492.87 & 11 & - & \\
\hline
\end{tabular}

Determination of the MDA level in BPR hens and cocks of two age categories

BPR hens and cocks were tested in the period before sexual maturity (123 days of age) and in the period of maximum egg laying (205 days of age). Analyzed samples were obtained from two genetically similar groups kept under different conditions of nutrition. In both age categories under a complex evaluation of birds kept under different conditions of nutrition, the average values of lipid peroxidation were lower in cocks; at the same time, the values of the MDA concentration at the age of 205 days

in both the hens and the cocks were twice as high as the values obtained at the age of 123 days (Fig. 1).Using two-factorial variance analysis (Tab. 3) it was found that the effect of sex on the intensity of lipid peroxidation was statistically significant, the effect of age statistically highly significant; however, no interaction was found between sex and age. Also the effect of age was observed in the variability of the character studied, i. e. in its decrease. The values of the variation coefficient in the 1st and 2nd measurements were $68 \%$ and $54 \%$, resp., for the cocks, and $45 \%$ and $34 \%$, resp., for the hens (Tab. 4).

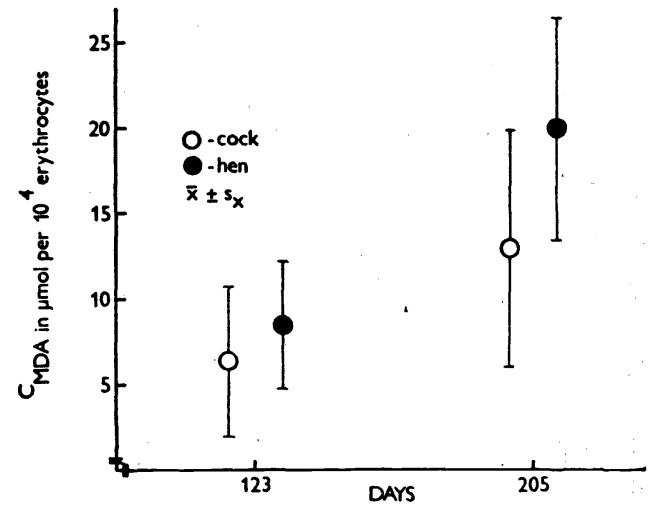

Fig. 1.

Average concentration of malonyldialdehyde in a suspension of red blood corpuscles of the BPR breed after aerobic incubation with $\mathrm{H}_{2} \mathrm{O}_{2}$.

Table 3

Two-factorial variance analysis of malonyldialdehyde concentration in a suspension of red blood corpuscles of the BPR breed

\begin{tabular}{|c|c|c|c|c|}
\hline Source of variability & Sum of squares & Degree of freedom & Variances & Value $\mathbf{F}$ \\
\hline $\begin{array}{l}\text { Sex } \\
\text { Age } \\
\text { Interaction } \\
\text { Factors known total } \\
\text { Within groups } \\
\text { (Residuum) }\end{array}$ & $\begin{array}{r}229.40 \\
937.71 \\
54.96 \\
1222.15 \\
1427.75\end{array}$ & $\begin{array}{r}1 \\
1 \\
1 \\
3 \\
44\end{array}$ & $\begin{array}{r}229.40 \\
937.71 \\
54.96 \\
407.38 \\
32.45\end{array}$ & $\begin{array}{c}7.0693^{*} \\
28.8971^{* *} \\
1.6936 \\
12.5541^{* *}\end{array}$ \\
\hline Total & 2649.90 & 47 & & \\
\hline
\end{tabular}

$* P=0.05, \quad * * P=0.01$ 
Table 4

Two-factorial variance analysis of malonyldialdehyde concentration in a suspension of red blood corpuscles of the BPR breed in relationship to age

\begin{tabular}{|c|c|c|c|c|c|c|c|c|}
\hline \multirow{2}{*}{$\begin{array}{l}\text { Source of } \\
\text { variability }\end{array}$} & \multicolumn{4}{|c|}{ Age 123 days } & \multicolumn{4}{|c|}{ Age 205 days } \\
\hline & $\begin{array}{l}\text { Sum of } \\
\text { squares }\end{array}$ & $\begin{array}{l}\text { Degree of } \\
\text { freedom }\end{array}$ & Variances & $\underset{F}{\text { Value }}$ & $\begin{array}{l}\text { Sum of } \\
\text { squares }\end{array}$ & $\begin{array}{l}\text { Degree of } \\
\text { freedom }\end{array}$ & Variances & $\underset{F}{\text { Value }}$ \\
\hline $\begin{array}{l}\text { Sex } \\
\text { Nutrition } \\
\text { Interaction }\end{array}$ & $\begin{array}{l}28.38 \\
35.53 \\
18.13\end{array}$ & $\begin{array}{l}1 \\
1 \\
1\end{array}$ & $\begin{array}{l}28.38 \\
35.53 \\
18.13\end{array}$ & $\begin{array}{l}1.73 \\
2.17 \\
1.11\end{array}$ & $\begin{array}{r}250.17 \\
480.55 \\
6.44\end{array}$ & $\begin{array}{l}1 \\
1 \\
1\end{array}$ & $\begin{array}{r}250.17 \\
480.55 \\
6.44\end{array}$ & $\begin{array}{c}8.91^{* *} \\
17.12^{* *} \\
0.23\end{array}$ \\
\hline $\begin{array}{l}\text { total } \\
\text { Within groups } \\
\text { (Residuum) }\end{array}$ & $\begin{array}{r}82.04 \\
327.55\end{array}$ & $\begin{array}{r}3 \\
20\end{array}$ & $\begin{array}{l}27.34 \\
16.38\end{array}$ & 1.67 & $\begin{array}{l}737.16 \\
561.16\end{array}$ & $\begin{array}{r}3 \\
20\end{array}$ & $\begin{array}{r}245.72 \\
28.06\end{array}$ & $8.75^{* *}$ \\
\hline Total & 409.59 & 23 & & & 1298.40 & 23 & & \\
\hline
\end{tabular}

$* * P=0.01$

gives a more detailed evaluation of the effect of age on the differences between sex in the MDA concentration. The table shows that the sex factor was significant only during the egg laying period.

\section{MDA level in BPR hens and cocks under conditions of different nutrition}

The samples of the BPR breed were from two genetically similar groups reared under different conditions of nutrition. The average values of MDA concentra-

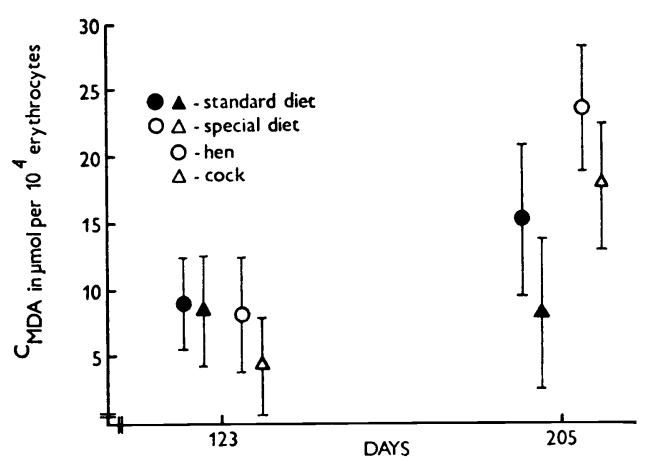
tion of birds of both sexes given standard nutrition in the period before sexual maturity were higher as compared with hens and cocks given special nutrition; however, during the egg laying period (205 days of age) the situation was reverse (Fig 2). Twofactorial variance analysis of the MDA

Fig. 2.

Average concentration of malonyldialdehyde in a suspension of red blood corpuscles of the BPR breed as affected by nutrition and age.

Table 5

Two-factorial variance analysis of malonyldialdehyde concentration in a suspension of red blood corpuscles of the BPR breed as related to different nutrition

\begin{tabular}{|c|c|c|c|c|c|c|c|c|}
\hline \multirow{2}{*}{$\begin{array}{l}\text { Source of } \\
\text { variability }\end{array}$} & \multicolumn{4}{|c|}{ Standard Nutrition I. } & \multicolumn{4}{|c|}{ Special nutrition II. } \\
\hline & $\begin{array}{l}\text { Sum of } \\
\text { squares }\end{array}$ & $\begin{array}{l}\text { Degree of } \\
\text { freedom }\end{array}$ & Variances & $\underset{F}{\text { Value }}$ & $\begin{array}{l}\text { Sum of } \\
\text { squares }\end{array}$ & $\begin{array}{l}\text { Degree of } \\
\text { freedom }\end{array}$ & Variances & $\underset{F}{\text { Value }}$ \\
\hline $\begin{array}{l}\text { Sex } \\
\text { Age } \\
\text { Interaction }\end{array}$ & $\begin{array}{l}83.35 \\
56.76 \\
70.42\end{array}$ & $\begin{array}{l}1 \\
1 \\
1\end{array}$ & $\begin{array}{l}83.35 \\
56.76 \\
70.42\end{array}$ & $\begin{array}{l}3.37 \\
2.29 \\
2.85\end{array}$ & $\begin{array}{r}144.74 \\
1275.73 \\
2.40\end{array}$ & $\begin{array}{l}1 \\
1 \\
1\end{array}$ & $\begin{array}{r}144.74 \\
1275.73 \\
2.40\end{array}$ & \begin{tabular}{|l}
$7.34^{*}$ \\
$64.72^{* *}$ \\
0.12
\end{tabular} \\
\hline $\begin{array}{l}\text { total } \\
\text { Within groups }\end{array}$ & 210.53 & 3 & 70.18 & 2.84 & 1422.87 & 3 & 474.29 & $24.06 * *$ \\
\hline (Residuum) & 494.52 & 20 & 24.73 & & 394.20 & 20 & 19.71 & \\
\hline Total & 705.06 & 23 & & & 1817.07 & 23 & & \\
\hline
\end{tabular}

$* P=0.05, * * P=0.01$ 
concentration in a suspension of erythrocytes performed separately because of the different nutrition proved that the effect of age was statistically significant only in fowls given special nutrition (Tab. 5). More detailed analyses of this effect proved that the effect of sex was significant only at the age of 205 days (Tab. 4). The effect of age on the intensity of lipid peroxidation in the period of sexual maturity was found to be highly significant in birds of both sexes given special nutrition (Tabs. 4 and 5), whereas no differences were found at the age of 123 days (before sexual maturity) as regards sex and nutrition (Tab. 4).

\section{Discussion}

The effect of hydrogen peroxide proved the lipid peroxidation potential of erythrocytes of the domestic fowl manifested in MDA formation, which is in accordance with the results of Stocks and Dormandy (1971) on the effects of hydrogen peroxide on the lipid components of erythrocytes of man. The erythrocytes not activated by peroxide revealed a low peroxidation activity, a fact very surprising due to the high phospholipid content and high intracellular concentration of oxygen and haemoglobin which represent strong catalysts of peroxidation.

Bivalent ions of copper used in studies of linoleic acid peroxidation (Haase and Dunkley 1969) and cells (Smutná 1975) evoked a fine precipitate in the final solutions even though the primary filtrate with trichloroacetic acid was completely clear.

In a general evaluation of the problem, it is necessary to draw attention to the peculiarities of the morphology of bird erythrocytes consisting of a nucleus, "mitochondria" and endoplasmic reticulum. Further, several properties of the superficial membrane of erythrocytes were described in the domestic fowl modified during the egg laying period, i. e. the agglutinability of the blood corpuscles with viruses (Salminen 1959), manifestation of the Hi agglutinogen (Scheinberck and Reckel 1962) and the lysis of blood corpuscles of the domestic fowl with fluids of the sexual glands of some species of farm animals (Petrovský and Babák 1973).

It is noteworthy that birds are capable of utilizing relatively large amounts of fats from the diet, whilst the mixture should be enriched with some antioxidation substances only when the doses are high (vitamin E and selenium). During the egg laying period there is a transport of enormous quantities of lipids in the organism of the domestic fowl, which, undoubtedly, bears evidence of the existence of a highly effective antiperoxidation system. Last but not least, it is necessary to bear in mind that the resulting peroxidation capability of tissues and cells is the product of a very complex interaction in which the instantaneous concentration of unsaturated fatty acids (substrate of reaction), presence of substances and activators capable of oxidation and, finally, the presence of inhibitors participate. For the time being, we cannot define which component of reaction affected the factors studied because we have no comparable information about the effect of factors of the external and internal milieu on the lipid peroxidation potential of erythrocytes of the domestic fowl.

In general, we assume that the methods elaborated for the quantitative studies of lipid peroxidation of erythrocytes of the domestic fowl will be continued in many future investigations of a theoretical and practical character. 


\section{Variabilita lipoperoxidačního potenciálu erytrocytů kura}

V práci byla sledována problematika peroxidace lipidů membrán erytrocytů kura. Při vypracování optimální metodiky jsme jako aktivátoru použili peroxid vodiku. Pł̌i studiu proměnlivosti koncentrace lipoperoxidačního potenciálu jsme zjistili, že variabilita této vlastnosti je ovlivňována řadou faktorů, jako jsou stáŕ, pohlaví, pohlavní dospělost a výživa. Před pohlavní dospělostí nebyly zjištěny výrazné rozdíly mezi jedinci obou pohlaví. V době pohlavní dospělosti se slepice vyznačovaly vyšši koncentrací malonyldialdehydu než kohouti. Ve vzorcích získaných od jedincủ odchovávaných a chovaných pomocí standardních smèsí podle CS receptur (KZK) nebyla hladina malonyldialdehydu ovlivněna ani stářím, ani pohlavím. Naproti tomu krmeni biologicky hodnotnějši směsí $(K) \mathbf{v}$ odchovu a směsí $s$ vysokým obsahem kukuruice $v$ době snášky vedlo $k$ manifestaci statisticky prủkazných rozdilủ vlivem stáŕí i pohlaví.

\section{Разновидность липоперекисного потенциала эритроцитов курицы}

В работе рассматривалась проблематика получения перекиси липидов мембран эритроцитов курицы. В ходе разработки оптимальной методики была нами в качестве активатора использована перекись водорода. В процессе изучения разновидности концентрации липоперекисного потенциала нами было установлено, что изменчивость данного свойства находится под влиянием целого ряда факторов, как например, возраст, пол, половая зрелость и питание. Перед половой зрелостью не была выявлена существенная разница между индивидуумами обоих полов. Во время половой зрелости курицы отличались по сравнению с петухами большей концентрацией малонового альдегида. В полученных у отдельных птиц, выращиваемых и откармливаемых с помощыю стандартных смесей по чехословацким рецептам [KZK), образцах уровень малонового альдегида не был под влиянием ни возраста, ни пола. В противовес этому кормление биологически более качественной смесью $(\mathrm{K})$ в выкорме и смесью с большим содержанием кукурузы во время носкости привели к статистически существенной разнице вследствие возраста и пола.

\section{References}

BARBER, A. A.: Lipid peroxidation in rat tissue homogenates: Interaction of iron and ascorbic acid as the normal catalytic mechanism. Lipids, 1, 1966: 146-151.

BARBER, A. A. - BERNHEIM, F.: Lipid peroxidation, its measurements, occurence and significance in animal tissues. Adv. Gerontol. Res., 2, 1967: 355-403.

BERNHEIM, F.: Biochemical implications of pro-oxidants and antioxidants. Rad. Res. 1963 (Suppl.), 3, 17-32.

HAASE, G. W. L. - DUNKLEY, W. L.: Ascorbic acid and copper in linoleate oxidation. II. Ascorbic acid and copper as oxidation catalysts. J. Lipid Res., 10, 1969: 561-567.

HEATH, R. L. - PACKER, L.: Effect of light on lipid peroxidation in chloroplasts. Biochem. biophys. Res. Commun., 19, 1965: 716-720.

OKUMA, M. - STEINER, M. - BALDINI, M.: Studies on lipid peroxides in platelets. I. Method of assay and effect of storage. J. Lab. Clin. Med., 75, 1970: 283-296.

PETROVSKY, E. - BABÁK, A.: Lytické pủsobení některých tekutin pohlavního traktu skotu a prasat na erytrocyty slepic. Vet. Med., 18, 1973: 53-62.

PLACER, Z.: Lipoperoxidační katabolismus polyenových mastných kyselin. Čas. Lék. čes., 107, 1968: $442-445$.

SALMINEN, A.: Differences in the agglutinability of rooster and hen erytrocytes by tick borne encephalitis virus. Ann. Med. exp. Fenn., 37, 1959: 400-403. 
SHARMA, S. - MUKHTAR, H. - SHARMA, S. - MURT, C.: Lipid peroxide formation in experimental inflammation. Biochem. Pharmacol., 21, 1972: 1210-1214.

SCHEINBERCK, S. L. - RECKEL, R. P.: Studies on the "Hi" agglutinogen in chickens. Ann. N. Y. Acad. Sci., 97, 1962: 194-199.

SMUTNÁ, M.: Výzkum peroxidace mastných kyselin a metabolismus fosfolipidú spermí. Project report VƯ P 11-329-051-05/03, VŠV Brno, 1975: 1-60.

STOCKS, J. - DORMANDY, T. L.: The autoxidation of human red cell lipids induced by hydrogen peroxide. Brit. J. Haem., 20, 1971: 95-101.

STOSSEL, T. P. - MASON, R. J. - SMITH, A. L.: Lipid peroxidation byhu uman blood phagocytes. J. Clin. Invest., 54, 1974: 638-645.

THIELE, E. H. - HUFF, J. W.: Quantitative measurement of lipid peroxide formation by normal liver mitochondria under various conditions. Archs Biochem. Biophys., 88, 1960: 203-207.

WILLS, E. D.: Lipid peroxide formation in microsomes - General considerations. Biochem. J., 113, 1969: 315-324. 